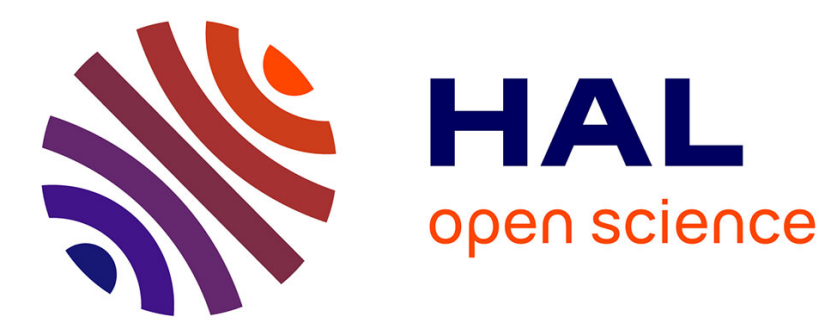

\title{
Human capital investment and long-term poverty reduction in rural Mexico
}

Paul Winters, Vera Chiodi

\section{To cite this version:}

Paul Winters, Vera Chiodi. Human capital investment and long-term poverty reduction in rural Mexico. 2008. halshs-00586227

\section{HAL Id: halshs-00586227 https://shs.hal.science/halshs-00586227}

Preprint submitted on 15 Apr 2011

HAL is a multi-disciplinary open access archive for the deposit and dissemination of scientific research documents, whether they are published or not. The documents may come from teaching and research institutions in France or abroad, or from public or private research centers.
L'archive ouverte pluridisciplinaire HAL, est destinée au dépôt et à la diffusion de documents scientifiques de niveau recherche, publiés ou non, émanant des établissements d'enseignement et de recherche français ou étrangers, des laboratoires publics ou privés. 


\section{PARLS SCHOOL OF ECONOMICS}

WORKING PAPER N² 2008 - 51

Human capital investment and long-term poverty

reduction in rural Mexico

Paul Winters

Vera Chiodi

JEL Codes: R11, R12, 018

Keywords: rural development, livelihood strategies, human capital, conditional cash transfers, Oportunidades, Mexico, Latin America

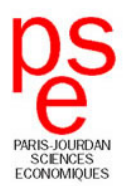




\title{
Human capital investment and long-term poverty reduction in rural Mexico
}

\author{
Paul Winters * \\ Vera Chiodi ${ }^{\dagger}$
}

March, 2008

\begin{abstract}
By focusing on human capital investment, the Mexican Oportunidades program will influence the economic choices of the rural poor. To understand how beneficiaries may alter their behaviour as a result of this intervention, this paper uses administrative data to analyze the economic activities of the Mexican rural poor. Results indicate that investments in education are likely to shift recipients from agricultural wage employment toward non-farm wage employment. The magnitude of this impact will be influenced by household assets and by the location of the household. The results suggest the need for policies that complement the government's focus on human capital investment.
\end{abstract}

Key words: rural development, livelihood strategies, human capital, conditional cash transfers, Oportunidades, Mexico, Latin America

\section{(Submitted at Journal of International Development)}

\footnotetext{
*American University - Associate Professor Department of Economics; 4400 Massachusetts Avenue, NW Washington, DC 20016. Email: winters@american.edu

${ }^{\dagger}$ PSE - Paris School of Economics; 48 boulevard Jourdan, 75014 Paris. Email: chiodi@pse.ens.fr
} 


\section{Oportunidades, Contigo and rural income-generating activities}

Sixty-seven percent of rural Mexicans are moderately poor and about half of those are extremely poor (World Bank, 2005). To address chronic poverty, the Mexican government has developed an overall strategy for poverty reduction referred to as Contigo. Contigo is not a specific program, but "a vision of social development with clear objectives and concrete lines of action." ${ }^{1}$ Government programs included under the Contigo umbrella are grouped into four areas: 1) improvements in human development, 2) opportunities for income generation, 3) asset accumulation, and 4) provision of social protection (Contigo, 2006). As a framework for addressing poverty, Contigo tries to integrate programs into a coherent poverty-reduction strategy. However, operationalisation has proved difficult given that over 200 programs have been incorporated as part of the strategy. An assessment of the strategy notes that while social policies for the poor are well developed, policies for their income growth are not (World Bank, 2004). Yet, this income component is critical for addressing extreme rural poverty, especially in the short run.

Oportunidades is a central element of the Mexican government's Contigo strategy. Launched in 1997 under the name Progresa, the program provides cash to beneficiary households provided that they meet certain conditions related to human capital development. The program reaches over 5 million beneficiaries including over 3 million in rural areas and constitutes Mexico's largest safety net. Since Oportunidades provides significant quantities of cash to beneficiaries, it has the potential not just to improve human capital development, but also to influence the income-generating activities of beneficiary households.

Oportunidades influences rural income-generation through three mechanisms. First,

\footnotetext{
${ }^{1}$ Authors' translation from the web page "Qué es Contigo?" (Contigo, 2006).
} 
by promoting investment in human capital, the program alters the long-run asset position of the household, especially the second generation which receives the bulk of the benefits. The influence this investment has on rural income-generation depends largely on the returns to education for rural households. Second, transfers provide a resource that may be used by households to invest in productive activities which may assist the household in exiting poverty in the shorter-run. Finally, Oportunidades may influence rural income-generation through demand linkages and spill over effects; that is, the additional income provided by the program may be spent on consumption goods which may induce a multiplying effect in the rural economy. Determining the total effect of Oportunidades on rural income-generation is beyond the scope of this paper. The objective of this paper is to understand the potential function of Oportunidades in a broader Contigo strategy for rural areas through analyzing the income-generating activities of recipient households. This will provide insight into the first two mechanisms through which Oportunidades may influence rural income-generation and help to identify complementary actions that can be taken as part of the overall Contigo strategy to alleviate rural poverty.

Research on the livelihood strategies of rural households has highlighted the significant diversity of rural income-generating activities (RIGAs) and the growing importance of rural non-farm economy suggesting that nearly 50 percent of rural income in developing countries is generated within non-farm sectors (Davis et al, 2007). Even within these broad categories of agricultural and non-farm activities, there remains significant variably in the economic activities suggesting there are multiple paths out of poverty. Like other countries, data from Mexico clearly highlights the fact that rural households are involved in a range of activities (Taylor and YunezNaude, 2000; Winters, Davis and Corral, 2002; World Bank, 2005). According to the ENIGH data used by the World Bank (2005), agricultural self-employment activities represent only $25 \%$ of total income generated for rural households while agricultural and non-farm wage earning represent nearly 50 percent. Oportunidades' recipients 
are by definition the extreme poor in Mexico. As such, the first question addressed in this paper is whether their patterns of income-generating activities mirror those of the rest of rural Mexico or if they are less diversified or more focus on particular activities.

The analysis of RIGAs considers the asset position of households as a key determinant of participation in activities as well as the intensity of involvement. Given an initial asset endowment, a household's choice of activities is viewed as depending on the context in which the household operates as well as preferences. Entering a particular activity depends on both pull factors, such as higher relative earnings compared to other activities, and push factors such as land constraints or credit market imperfections. The combination of activities chosen by the household leads to a certain level of income for the household in the period under study. The mapping of assets to income through activities as is done in these analyses can be viewed as similar to a production process with assets corresponding to factors of production and income as the output of that process (Barrett and Reardon, 2000).

Cross country studies of RIGAs suggest some clear relationships between these activities and household endowment. Of noteworthy importance is schooling which appears to be strongly and positively correlated with rural non-farm (RNF) wage employment and negatively correlated with agricultural wage employment. This suggests the returns to education are primarily in RNF wage activities versus agricultural wage activities. Similarly, land endowment is clearly linked to both crop and livestock production as are ownership of other agricultural assets. Both, however, are negatively related to wage employment. Finally, the level of infrastructure and proximity to rural towns and urban centres also appear important influencing participation in wage activities in particular (Winters et al, 2007). While previous studies have shown these general relationships between assets and activity choice, it is unclear whether these patterns hold for the extreme poor. Another issue addressed in this paper is whether schooling and proximity to population centres play 
a key role in the economic choices of the extreme poor in rural areas.

By providing cash and promoting human capital development, Oportunidades can have a considerable effect on the decision making of recipient households with respect to economic activity both of this and the subsequent generation. As noted, whether investment in education is still linked to non-farm wage employment even among this population is open to question. Furthermore, a key question to ask is whether education investment is sufficient to improve the well-being of the children of the poor or if complementary actions, similar to those envisioned in the Contigo strategy, are necessary. Among other considerations, as noted above, location seems to play an important role in the economic choices of households. This raises the question of whether education and location are complements-that is, whether returns to education vary by location suggesting that the returns to investment in education are going to be location specific. There is some evidence that economic activities depend on location (Fafchamp and Shilpi, 2003; Winters et al 2007), but no evidence on the relationship between education and location. An important contribution of this paper is then to consider how educational returns vary across location. In particular, we examine how returns vary based on distance to population centres, including rural towns, small urban centres and cities. We also examine if they vary by region within Mexico.

Along with location, it is also likely the case that returns to education are linked to other household assets and vary depending on these assets. If so, the returns to Oportunidades investment will depend on the other assets of the household. To assess whether this is the case, we consider whether the influence of education on economic activities depends on how marginal the communities are.

In this paper, while examining a number of factors that influence the economic choices of the Mexican rural poor, we focus particularly on education and how educational returns vary particularly by location and asset position. If returns vary substantially, it suggests other actions may be necessary to enhance such returns and 
that Oportunidades without Contigo is likely to have lesser returns. While other studies suggest this may be the case, the data used in this study is from actual Oportunidades recipients who are the extreme rural poor in Mexico and thus allows directly testing of these relationships. This data is discussed in the next section. It is followed in Section III by a presentation of the empirical approach to analyzing the data. Section IV then presents the results of this analysis while the conclusions and policy implications are presented in the final section.

\section{Oportunidades' administrative data}

To address the questions noted in the first section, we use administrative data from the Oportunidades program. As part of the administrative practice of the program, when a rural locality is targeted a census of all households living in that locality is taken. This census-referred to as the Survey of Socioeconomic Characteristics of Rural Households (ENCASEH)-includes detailed information on each beneficiary household, including household demographics, income level and sources, education, assets, and so forth. The administrative data also includes community-level data such as the marginality index ${ }^{2}$ that was used for targeting communities as well as the "score" (or puntaje) which is the asset index that determines household eligibility for the program. In this paper, we focus on rural areas (defined as communities with less than 2,500 inhabitants) since this is where most of the extreme poor in Mexico reside and where addressing chronic poverty has proved most difficult. For this analysis, a random sample of 10 percent of localities was taken for a total of just over 6,000 communities and approximately 180,000 eligible households. The data is unique in that it identifies the extreme poor in Mexico through an asset-based index (puntaje) and is a large sample of this population. It is a valuable data set since it

\footnotetext{
${ }^{2}$ The marginality index can be used as a proxy for the degree of access to basic goods and services at community level and thus gives a sense of how remote, and correspondingly poor, a community is.
} 
can be viewed as representative of the extreme rural poor in Mexico.

Based on the information available in the ENCASEH, income aggregates were created and broken down into five categories: agricultural wage employment, non-farm wage employment, self employment, transfers and other. These categories sum to total income of the household in the year prior to the survey. Since the income comes from different years depending on entry into Oportunidades (1996-2000), monetary values are put into real 2000 pesos. The median value for income is approximately 13,000 pesos per household and the mean 18,000 pesos per household. ${ }^{3}$

Table 1 provides a breakdown of the participation in and income earned from the five categories of income. Just over half of recipient households participate in agricultural wage activities and 41 percent of the income earned is from agricultural wage employment making it the most important activity of the extreme rural poor. Self-employment income is next in importance for recipients with 29 percent of households participating and 18 percent of income earned. While nearly one-third of recipient households receive transfers ${ }^{4}$, it represents less than 10 percent of total income. Only one in five recipient households receives income from non-farm wage employment yet it makes up nearly a quarter of total income. Note also that on average those who participate in rural non-farm wage employment earn much more than from other activities, particularly agricultural wage. Clearly, there are likely to be non-farm wage employment activities that are low productivity and provide a similar income to labourers as agricultural wage activities, but the higher average income suggests there are also higher productivity non-farm wage activities that provide a potential path out of poverty.

\footnotetext{
${ }^{3}$ This corresponds to a per capita median income of 2,800 pesos/capita per year (approximately US $\$ 270 /$ capita per year) and a mean per capita income of 3,700 pesos (approximately US $\$ 355 /$ capita per year).

${ }^{4}$ The data is from the baseline census that occurred prior to the initiation of Oportunidades in the community and transfers do not include receipt of Oportunidades transfers.
} 
Table 1: Participation and income aggregates

\begin{tabular}{lcccc} 
& $\begin{array}{c}\text { Participation in } \\
\text { activity }\end{array}$ & $\begin{array}{c}\text { Average income } \\
\text { for all households }\end{array}$ & $\begin{array}{c}\text { Share of total } \\
\text { income }\end{array}$ & $\begin{array}{c}\text { Average income } \\
\text { for participants }\end{array}$ \\
\hline Agricultural wage income & $52.7 \%$ & 7511 & $41.4 \%$ & 14246 \\
Non-agricultural wage income & $19.6 \%$ & 4388 & $24.2 \%$ & 22345 \\
Self-employment income & $28.8 \%$ & 3259 & $18.0 \%$ & 11330 \\
Transfers income & $32.6 \%$ & 1797 & $9.9 \%$ & 5510 \\
Other income & $11.1 \%$ & 1190 & $6.6 \%$ & 10706 \\
\hline Total & & 18146 & $100 \%$ &
\end{tabular}

Table 2 provides an overview of the basic characteristics of households in the sample. The education levels of the household heads in the sample are remarkably low. Nearly one-third have no education and over 70 percent have not completed primary school. Furthermore, less that 10 percent have any secondary education or higher. The median age of recipients is 41 years of age and the mean is 44 . Looking at the education levels for the older 50 percent (over 41) and younger 50 percent (under 41) of recipients, we find that the younger heads do have higher levels of education. On average of those under 41, 15 percent have no education, 40 percent some primary, 31 percent completed primary education and 12 percent at least enrolled in secondary education. While this suggests a general increases in education over time, these numbers suggest very low levels education among the recipient population.

Nearly 10 percent of households are single, female-headed households and over one-quarter are indigenous speakers. Indigenous groups have generally been among the poorest in Mexico and may have special needs compared to the rest of the Oportunidades population. On average, households have 2.7 workers defined as those over 14 and less than 65 years old. In terms of assets, the puntaje variable provides an asset index that was used to determine eligibility of the program with a higher score meaning a lower asset position. The average value for the asset index is 2.7 and values range from 0.69 (the lower cut-off to be included in the program) up to 8 although the majority of the households lie between 1 and 5 . 
Table 2: Household charactersitics

$\begin{array}{lc} & \text { Means or } \\ \text { percents }\end{array}$

In rural areas of developing countries, work animals are a key mechanism for storing wealth and managing production. On average, Oportunidades households own 0.64 livestock. However, note that over 70 percent of recipients own no work animals and only $15 \%$ own more than one animal. A similar pattern can be seen for land. On average, recipient households have access to 2.44 hectares of land but over 50 percent have no access to land and only 10 percent have access to five or more hectares. The results show that Oportunidades households, as expected, are extremely asset poor.

A number of community variables are included in the data set most importantly variables measuring distance to population centres. The location of households relative to population centres is expected to have a significant impact on the predominant activities in an area. For this study, following the definitions used by the Mexican government, three types of population centres are identified, i) rural towns with populations between 5,000 and 15,000, ii) small urban centres with populations between 
15,000 and 100,000, and iii) cities with over 100,000 people. On average, households are $21 \mathrm{~km}$ to rural towns, $31 \mathrm{~km}$ to small urban centres and $64 \mathrm{~km}$ to cities.

\section{Analyzing income generation: the empirical ap- proach}

To systematically analyze households' choices with respect to income-generating activities, the most common approach is to use a two step method in which the first step is to assess the factors that influence participation in individual activities and the second step to consider the level of income from that activity for those who participate. The reason for distinguishing the participation choice and the intensity of involvement is that there are likely to be barriers to entry that limit participation. If this is the case, the factors influencing the choice of participation may differ from those influencing the intensity of involvement. This suggests looking at these two decisions independently as opposed to jointly through, for example, using a censored regression approach.

Participation in income-generating activities is a discrete choice thus requiring a discrete dependent variable model. For this paper, a probit model is used to examine the choice of participating in the five income-generating activities: self employment (including agricultural and non-farm activities), agricultural wage employment, nonfarm wage employment, transfers and other income sources.

To examine the levels of income, we use an ordinary least squares of the natural logarithm of positive values of income. This follows the practice used elsewhere of using two-tiered (hurdle) models when confronted with censored data (Deb, Manning and Partha, 2005; Hertz, 2007). The transformation of the income data into logarithmic form allows not only interpretation of results in percent change but also 
since income data is generally appropriate for income data since it follows a normal distribution when logged. ${ }^{5}$ An alternative to this two-tiered approach would be to use Heckman's two-stage procedure in which the second stage regressions on the level of income would include the variables expected to influence income levels as well as the inverse Mills ratio (IMR). The IMR is constructed from the errors of the participation equation and is used to test for selection bias and to control for unobservable household characteristics. A major problem with this approach is that it requires instruments in the first stage that predict participation in the income-generating activities but do not influence the level of income earned. When such instruments are not available-as in this case-the results are suspect (Deaton, 1997). Furthermore, using a two-tiered model assumes that our interest is in modelling observed outcomes (zero is valid data representing an optimizing agents corner solution) and not potential outcomes as in the Heckman approach where zero are censored observations of a latent variables (Hertz, 2007). This assumption seems reasonable in the context studied here although it does require careful interpretation of the meaning of estimated coefficients. The use of a two-tiered model also allows for the use of logged positive effects and straightforward calculation of marginal effects since calculated coefficients is an elasticity if, as done here, continuous variables are included as natural logs.

The household characteristics noted in Table 2 are those that are hypothesized to be linked to RIGAs. Along with these variables, time dummy variables are included in both regressions for year of the census to control for differences across time and state dummy variables are included to control for state fixed effects. Given the crosssectional nature of the data establishing causation between assets and community factors and RIGAs is complicated. For this reason, in the analysis below we remain cautious about stating causality. However, given the strength of the results and the

\footnotetext{
${ }^{5}$ Plots of the income distributions for all the income categories showed that in each case they appeared normally distributed once the natural log was calculated.
} 
consistency with these results and those found elsewhere, there does appear to be clear evidence of strong correlations between certain assets and activities and we do believe these have significant implications for policy.

\section{Factors influencing the income-generating choices of the poor}

Since our interest is in understanding the role of different factors in the incomegenerating activities of the poor, in what follows we examine results by key assets and present them in individual tables and figures.

Table 3 presents the results for schooling outcomes. The default category is no schooling for the household head so the presented effects give the influence of schooling levels going from no schooling to the noted level of schooling. As can be clearly seen from the results, the higher the level of schooling the lower probability of participating in agricultural wage employment, suggesting that agricultural wage is a refuge sector that generally is for those with very limited levels of education. Contrary to this effect, household heads with higher levels of schooling are significantly more likely to participate in non-farm wage employment activities with the probability of participating increasing with each level of schooling. The results for self employment suggest having some schooling increases the probability of participation, but the effect may be non-linear since the probability of participating in self employment is lower for those with the highest levels of schooling. This result is likely due to the fact that the self-employment category includes a range of agricultural and non-farm self employment that varies in terms of returns. Finally, as would be expected, transfers (which include both public and private transfers) are more likely to be received by those with some primary education, but not those with 
some secondary education.

Table 3: Schooling and income-generating activities

\begin{tabular}{|c|c|c|c|c|c|c|c|c|}
\hline \multirow[b]{2}{*}{ Participation } & \multicolumn{2}{|c|}{$\begin{array}{l}\text { Agricultural wage } \\
\text { employment } \\
\text { Marginal }\end{array}$} & \multicolumn{2}{|c|}{$\begin{array}{l}\text { Non-farm wage } \\
\text { employment } \\
\text { Marginal }\end{array}$} & \multicolumn{2}{|c|}{$\begin{array}{l}\text { Self employment } \\
\text { Marginal }\end{array}$} & \multicolumn{2}{|c|}{$\begin{array}{l}\text { Transfers } \\
\text { inal }\end{array}$} \\
\hline & effect & Z-stat & effect & Z-stat & effect & Z-stat & effect & Z-stat \\
\hline Some primary education & -0.04 & -12.48 *** & 0.01 & 4.61 *** & 0.04 & 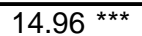 & 0.05 & 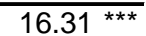 \\
\hline Primary education & -0.06 & $-15.18 * * *$ & 0.03 & $9.14 * * *$ & 0.03 & $8.42 * \star *$ & 0.02 & $5.48 * * *$ \\
\hline Some secondary or higher & -0.08 & $-13.60 * * *$ & 0.07 & 15.78 *** & -0.01 & -1.25 & -0.08 & $-14.13 * \star \star$ \\
\hline Income level (Logged) & Coef. & t-stat & Coef. & t-stat & Coef. & t-stat & Coef. & t-stat \\
\hline Some primary education & -0.014 & $-2.36^{\star \star \star}$ & 0.041 & $3.71^{\star \star \star}$ & 0.013 & 1.08 & -0.009 & -0.88 \\
\hline Primary education & -0.024 & $-3.23 * * \star$ & 0.083 & $6.19 * * *$ & 0.065 & $4.00 * \star *$ & -0.066 & $-4.36 * * *$ \\
\hline Some secondary or higher & -0.044 & $-4.41 * * *$ & 0.192 & $11.41 * * *$ & 0.213 & $8.77 * \star \star$ & -0.046 & $-1.70 *$ \\
\hline
\end{tabular}

Looking at the relationship between schooling and the income level from each activity, the results suggest high returns from schooling for non-farm wage employment and self employment, with increases in income with each level of schooling. Having a primary and secondary level of schooling clearly appears to pay off even for the poorest households in Mexico, particularly through these activities. Schooling is negatively associated with agricultural wage employment and the receipt of transfers.

Given that a primary focus of Oportunidades is on improving schooling outcomes and the fact that it appears to have been successful in improving schooling enrolment, attendance and progression (Skoufias, 2005), these results have important implications for the program and government policy. The results suggest that with increased schooling the expectation is that there will be a shift away from agricultural wage employment and towards more self employment and non-farm wage employment, particularly for those that complete some secondary level schooling. Rural non-farm employment in particular appears to be a key path out of poverty given the higher income to those with some secondary level education. This assumes, of course, that opportunities to enter into non-farm wage employment will be available to the newly educated. If not, the benefits of increased schooling in 
terms of income-generation may be limited at least for those who remain in rural areas. For others, migration to areas where income gains from schooling are higher may be the only option. Given the importance of schooling in the Oportunidades program, we consider this issue further in the analysis below.

Table 4 provides the results for the analysis of household demographic variables. The results indicate that as the age of the household head increases the probability of receiving transfers and participating in self employment also increases. Having an older head, however, reduces the probability of any wage employment. This corresponds with other evidence suggesting that households further along the life cycle are less likely to be involved in wage activities while younger household are more likely to be involved. Households with older household heads that participate in non-farm wage and self employment activities tend to receive lower levels of income from these activities, but more for the other activities.

Female-headed households appear to be much less likely to participate in agricultural wage employment and in general receive significantly lower income from all productive activities in which they participate. While female-headed households are much more likely to participate in rural non-farm employment, they receive significantly less returns suggesting they tend to participate in lower return activities. Female-headed households that receive transfers do get significantly more income from transfers than other households. Indigenous language speakers are slightly less likely to participate in wage activities, but are more likely to participate in self employment and receive transfers. In fact, being indigenous increases the probability of being self employed by nearly six percent. They generally receive less income in all activities compared to their Spanish-speaking counterparts. The influence of being a female-headed household or an indigenous language speaker on rural income generation strongly suggests the need to tailor programs that complement Oportu- 
nidades for these specific populations. Given the generally lower asset position of these households, as noted below, additional investment in assets may be necessary to provide sufficient returns to Oportunidades' investment in education.

Finally, labour size, not surprisingly, increases participation in all activities and leads to higher income from those activities since more members are likely to be participating. This result holds strongest for wage activities suggesting that limitations in land ownership or other household productive assets push larger households into employment activities. This is a common result and indicates that labour size is a push factor that drives households to participate in multiple activities.

Table 4: Household demographics and income-generating activities

\begin{tabular}{|c|c|c|c|c|c|c|c|c|}
\hline Participation & \multicolumn{2}{|c|}{$\begin{array}{l}\text { Agricultural wage } \\
\text { employment } \\
\text { Marginal }\end{array}$} & \multicolumn{2}{|c|}{$\begin{array}{l}\text { Non-farm wage } \\
\text { employment } \\
\text { Marginal }\end{array}$} & \multicolumn{2}{|c|}{$\begin{array}{l}\text { Self employment } \\
\text { Marginal }\end{array}$} & \multicolumn{2}{|c|}{$\begin{array}{l}\text { Transfers } \\
\text { Marginal }\end{array}$} \\
\hline Age of head & -0.002 & $-24.11 * \star \star$ & -0.002 & $-24.09 * \star \star$ & 0.002 & $28.02 * \star \star$ & 0.006 & $69.85 * \star \star$ \\
\hline Female headed & -0.172 & $-39.06 * \star \star$ & 0.098 & $27.13 * \star \star$ & 0.017 & 4.16 *** & 0.051 & $11.94 * \star *$ \\
\hline Indigenous speaker & -0.014 & $-3.96 * \star \star$ & -0.018 & $-6.50 * \star \star$ & 0.057 & 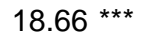 & 0.041 & 12.66 *** \\
\hline Labour size & 0.033 & 38.31 *** & 0.045 & 73.86 *** & 0.018 & 24.27 *** & 0.002 & 1.89 * \\
\hline Income level (Logged) & Coef. & t-stat & Coef. & t-stat & Coef. & t-stat & Coef. & t-stat \\
\hline Age of head (logged) & 0.049 & $6.35^{\star \star \star}$ & -0.124 & $-8.25 * \star \star$ & -0.068 & $-3.97^{\star \star \star}$ & 0.178 & $10.95 * \star \star$ \\
\hline Female headed & -0.047 & $-4.92 * \star \star$ & -0.148 & $-10.26 * \star \star$ & -0.089 & $-5.49 * \star \star$ & 0.306 & $19.00 * \star \star$ \\
\hline Indigenous speaker & -0.174 & $-24.01 * * *$ & -0.051 & $-3.64 * \star \star$ & -0.122 & $-8.91 * \star \star$ & -0.296 & $-24.54 * * *$ \\
\hline Labour size (logged +1) & 0.476 & 71.44 *** & 0.565 & $42.50 * \star \star$ & 0.370 & $32.01 * * *$ & -0.069 & $-6.90 * \star \star$ \\
\hline
\end{tabular}

Table 5 presents the results for the analysis of the primary measures of wealth including the puntaje, work animals owned and land use. The results for the puntaje variable suggest that the poorest households have a higher probability of working as agricultural wage labourers and receiving transfers and a lower probability of self employment and non-farm wage employment. Those with a higher puntaje also receive lower income from all activities. These results are not too surprising as they 
reflect the fact that agricultural wage employment is generally a low productivity activity and the only sector for which very asset poor, unskilled households can obtain income. Furthermore, it suggests the asset poor that are involved in other activities tend to be in lower return activities.

Table 5: Wealth and income-generating activities

\begin{tabular}{|c|c|c|c|c|c|c|c|c|}
\hline \multirow[b]{2}{*}{ Participation } & \multicolumn{2}{|c|}{$\begin{array}{r}\text { Agricultural wage } \\
\text { employment }\end{array}$} & \multicolumn{2}{|c|}{$\begin{array}{r}\text { Non-farm wage } \\
\text { employment }\end{array}$} & \multicolumn{2}{|c|}{ Self employment } & \multicolumn{2}{|c|}{ Transfers } \\
\hline & Marginal & Z-stat & Marginal & Z-stat & Marginal & Z-stat & Marginal & Z-stat \\
\hline Puntaje & 0.045 & 32.11 *** & -0.009 & $-8.87^{\star \star \star}$ & -0.017 & $-13.68 * \star \star$ & 0.023 & 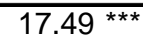 \\
\hline Work animals owned & -0.022 & $-12.85 * \star \star$ & -0.006 & $-6.60 * \star \star$ & 0.019 & $12.14 * \star \star$ & 0.030 & $12.97 * \star \star$ \\
\hline Land size & -0.003 & $-15.68 * * *$ & 0.000 & -1.24 & 0.002 & 14.83 *** & 0.003 & 14.40 *** \\
\hline Income level (Logged) & Coef. & t-stat & Coef. & t-stat & Coef. & t-stat & Coef. & t-stat \\
\hline Puntaje & -0.050 & $-8.44^{\star \star \star}$ & -0.167 & $-17.13^{\star \star \star}$ & -0.225 & $-17.68^{\star \star \star}$ & -0.174 & $-13.29 \star \star \star$ \\
\hline Work animals owned & -0.007 & -1.27 & -0.012 & -1.28 & -0.026 & $-2.84 * \star \star$ & 0.058 & 7.34 *** \\
\hline Land size & -0.002 & -0.45 & 0.006 & 0.93 & 0.043 & $7.05 * \star \star$ & 0.043 & 7.62 *** \\
\hline
\end{tabular}

This raises the question of whether providing education to the asset poor alone is sufficient to expand their opportunities. To explore this possibility, the probit regression was rerun to include interaction terms between education levels and the puntaje variable to determine if low asset position inhibits participation in wage activities even when the household has higher education levels. The results are reported in Table 6 . The sign of the individual variables remain the same as in the previous specification while the interaction terms are positive for agricultural wage employment and negative for non-farm wage employment. While the magnitudes of the marginal effects still imply education is negatively associated with agricultural wage and positively associated with non-farm wage, the signs of the interaction terms indicate that the influence of education on activity participation is significantly lower for households with a lower asset position thus suggestion the need to invest in other assets in combination with education.

Returning to Table 5, animal ownership is positively linked to self employment, 
Table 6: Schooling and asset position

\begin{tabular}{|c|c|c|c|c|}
\hline Participation & \multicolumn{2}{|c|}{$\begin{array}{c}\text { Agricultural wage } \\
\text { employment } \\
\text { Marginal }\end{array}$} & \multicolumn{2}{|c|}{$\begin{array}{l}\text { Non-farm wage } \\
\text { employment } \\
\text { Marginal }\end{array}$} \\
\hline Some primary education & -0.057 & $-10.73 * \star \star$ & 0.025 & $5.76 * \star \star x$ \\
\hline Primary education & -0.121 & $-19.96 * \star \star$ & 0.083 & $16.06 * * \star$ \\
\hline Some secondary or higher & -0.270 & $-40.89 * \star \star$ & 0.220 & $34.41 * * *$ \\
\hline Puntaje & 0.054 & $32.02 * \star *$ & -0.018 & $-12.28 * * *$ \\
\hline Some primary education * puntaje & 0.007 & $3.73 * \star \star$ & -0.005 & $-3.17 * \star \star$ \\
\hline Primary education * puntaje & 0.027 & $11.47 * \star \star$ & -0.022 & 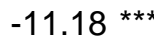 \\
\hline Some secondary or higher * puntaje & 0.092 & $28.15 * \star \star$ & -0.047 & $-18.65 * * *$ \\
\hline
\end{tabular}

Notes: Robust test statistics reported; *** indicates signficance at the $99 \%$ level, ${ }^{*} 95 \%$ level and * $90 \%$ level.

most likely via agricultural production and negatively associated with participation in wage activities. Land size follows a similar pattern although the effects are rather negligible probably because a large percentage of households in the survey have no access to land. The positive relationship between transfers and land size and work animals is likely due to agricultural programs such as PROCAMPO.

As noted previously, the location of households relative to population centres is expected to have a significant impact on the predominant activities in an area. This has been found for rural households in general (Fafchamps and Shilpi, 2003) and we wish to check this with the poorer households included in our data. The importance of activities may vary depending on the size of population centres and three types of population centres are identified, i) rural towns with populations between 5,000 and 15,000, ii) small urban centres with populations between 15,000 and 100,000 and iii) cities with over 100,000 people. The analysis of the distance of households to these centres is complicated by the fact the relationship is likely to be non-linear and the presence of one population centre may influence the effect of other centres. As such, the distance to each of these centres is modelled using a non-linear specificationnamely, a linear quadratic and cubed term for the participation equations and both a linear and squared natural log of the distance for the income equation-as well as interaction terms between each of the possible combinations of population centres. The results can be seen in Table 7 but because of the complicated mix of terms in 
some cases it is easier to interpret the results using predictions over the distances in question and we, therefore, present figures that show the relationship between distance to population centres and economic activity of the rural poor.

Table 7: Distance to population centres and income-generating activities

\begin{tabular}{|c|c|c|c|c|c|c|c|c|}
\hline \multirow[b]{2}{*}{ Participation } & \multicolumn{2}{|c|}{$\begin{array}{l}\text { Agricultural wage } \\
\text { employment } \\
\text { Marginal }\end{array}$} & \multicolumn{2}{|c|}{$\begin{array}{l}\text { Non-farm wage } \\
\text { employment } \\
\text { Marginal }\end{array}$} & \multicolumn{2}{|c|}{$\begin{array}{l}\text { Self employment } \\
\text { Marginal }\end{array}$} & \multicolumn{2}{|c|}{$\begin{array}{l}\text { Transfers } \\
\text { hal }\end{array}$} \\
\hline & effect & Z-stat & effect & Z-stat & effect & Z-stat & effect & Z-stat \\
\hline Distance to rural town & -0.00299 & 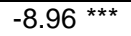 & -0.00157 & -6.19 *ᄎ & 0.00237 & $7.97^{\star \star \star}$ & 0.00600 & 18.92 ** \\
\hline Distance to rural town squared & 0.00002 & $3.41 * \star \star$ & 0.00004 & 8.28 ** & -0.00004 & 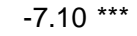 & -0.00009 & $-15.15 * \star \star$ \\
\hline Distance to rural town cubed & 0.00000 & -0.73 & 0.00000 & $-5.68 * \star$ & 0.00000 & $3.07 * \star \star$ & 0.00000 & 8.61 *** \\
\hline Distance to small centre & 0.00043 & 1.38 & -0.00277 & $-9.96 * \star$ & 0.00158 & $5.66 * \star \star$ & 0.00664 & $18.91 * * *$ \\
\hline Distance to small centre squared & -0.00001 & $-1.98 * \star$ & 0.00004 & $6.44 * *$ & -0.00001 & $-2.83 * \star *$ & -0.00012 & $-17.38 * \star \star$ \\
\hline Distance to small centre cubed & 0.00000 & $5.63 * \star \star$ & 0.00000 & -3.88 ** & 0.00000 & -1.09 & 0.00000 & $11.74 * \star \star$ \\
\hline Distance to city & 0.00309 & $11.43 * * *$ & -0.00241 & $-10.19 * *$ & 0.00005 & 0.21 & -0.00025 & -0.80 \\
\hline Distance to citysquared & -0.00001 & $-3.80 * \star \star$ & 0.00002 & $5.60 * \star$ & -0.00001 & $-2.12 * \star \star$ & 0.00001 & $2.63 * \star \star$ \\
\hline Distance to city cubed & 0.00000 & 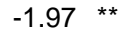 & 0.00000 & -2.25 ** & 0.00000 & $5.90 * \star \star$ & 0.00000 & $-3.64 * \star \star$ \\
\hline Town*small centre & -0.00002 & $-7.25 * \star \star$ & -0.00001 & $-3.01 * *$ & 0.00004 & 11.46 *** & 0.00001 & $4.41 * \star \star$ \\
\hline Town*city & 0.00001 & $4.02 * * *$ & -0.00001 & $-2.53 * \star$ & 0.00000 & -1.85 & 0.00000 & 0.90 \\
\hline Small centre*city & 0.00000 & -1.48 & 0.00000 & -0.63 & -0.00001 & $-6.35 * \star *$ & 0.00001 & 7.75 *** \\
\hline Income level (Logged) & Coef. & t-stat & Coef. & t-stat & Coef. & t-stat & Coef. & t-stat \\
\hline Log distance to rural town & -0.038 & -1.41 & 0.044 & 1.16 & -0.023 & -0.39 & 0.137 & $2.05^{\star \star *}$ \\
\hline Log distance to rural town squared & 0.004 & 0.95 & 0.019 & 2.72 ** & 0.054 & $6.30 * \star \star$ & 0.005 & 0.54 \\
\hline Log distance to small centre & -0.014 & -0.52 & 0.006 & 0.15 & -0.050 & -0.87 & 0.293 & $4.38^{\star \star \star}$ \\
\hline Log distance to small centre square & 0.031 & $9.06 * \star *$ & 0.009 & 1.47 & 0.011 & 1.29 & -0.024 & $-2.60 * \star *$ \\
\hline Log distance to city & -0.138 & $-4.25 * \star \star$ & -0.198 & $-4.35 * \star$ & -0.686 & $-10.36 * \star \star$ & -0.445 & $-5.55 * * *$ \\
\hline Log distance to city squared & 0.023 & $4.93 * * *$ & 0.032 & 4.56 ** & 0.107 & $12.97 * \star *$ & 0.071 & $6.71 * \star \star$ \\
\hline Town*small centre & -0.020 & $-4.12 \star \star \star *$ & -0.0 & -2.12 ** & -0.005 & -0.43 & -0.047 & $-3.60 * * *$ \\
\hline & 022 & $3.01 * * *$ & -0.020 & -1.92 & -0.067 & $-5.07 * \star *$ & -0.011 & -0.66 \\
\hline Small centre*city & -0.037 & $-6.85 * \star \star$ & -0.009 & -1.14 & -0.006 & -0.50 & -0.017 & -1.25 \\
\hline
\end{tabular}

Notes: Robust test statistics reported; ${ }^{* \star}$ indicates signficance at the $99 \%$ level, ${ }^{\star}$ 95\% level and $* 90 \%$ level.

Table 7 and Figure 1 present the relationship between distance to towns, small urban centres and cities, and the probability of participating in each of the incomegenerating activities. As can be seen, moving away from a rural town leads to a significant decline in the probability of agricultural employment from approximately a 60 percent probability to less than 50 percent. Similarly, being further from a small urban centre reduces the probability of agricultural wage employment although this is less dramatic. On the other hand, the further away a household is from a city the much greater the probability of agricultural employment. Taken together the results indicate a concentration of participation of agricultural employment near 
smaller population centres and away from larger centres.

Figure 1: Probability of participation and distance to population centres.

Rural town

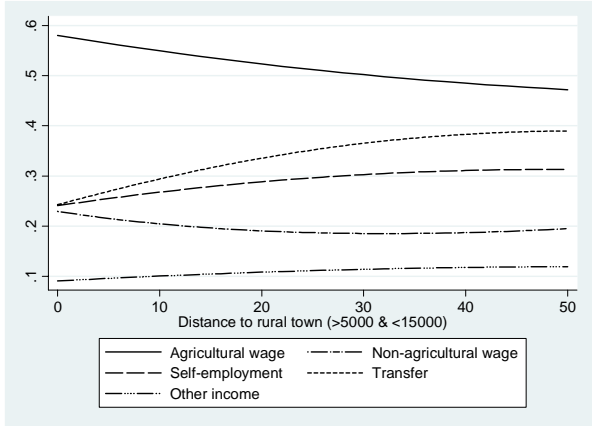

Small urban centre

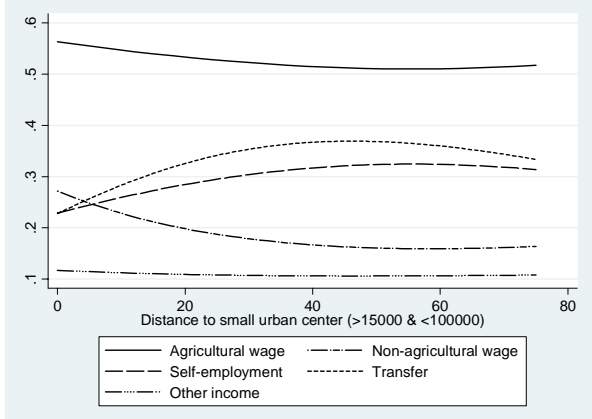

City

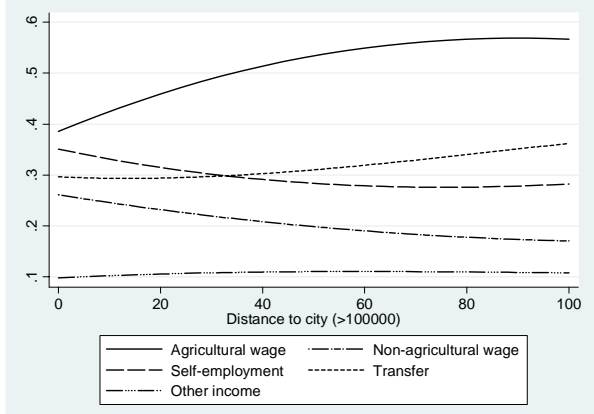


For non-farm wage employment, there is a decline in the probability of participation as you move away from any population centre. This decline is greatest for small urban centres and cities. Participation in self-employment activities slightly increase as you get further from smaller population centres probably due to the increased emphasis on agriculture in remote areas. There is a slight decline in self-employment participation as you get further away from cities most likely because of a decline in non-farm self-employment activities. The results clearly show the importance of location on the probability of participating in certain activities.

Figure 2 shows the relationship between distance and income earnings for participants from each activity. The results do not show any dramatic changes in the income from activities based on the distance from population centres. For nearly all productive activities there is an initial downward trend for income earned as the distance from the population centre increases. This initial change is more pronounced the larger the population centre so it is barely discernable near rural towns, but more dramatic for cities. After this initial change in income gains for participants in these activities, the returns tend to flatten out particularly beyond $5 \mathrm{~km}$ (for rural towns) to $20 \mathrm{~km}$ (for cities) from the population centre. Overall the results indicate that location seems to matter more for participation in activities as opposed to the returns to those activities and the remaining discussion focuses more on participation.

One of the questions we wish to address is the relationship between the distances to different urban centres. For example, whether being nearer or further from a city impacts the importance of being close to a small urban centre. To do this, interaction terms are included in the regressions. Figure 3 examines wage employment in order to determine if there is a relationship between towns and small urban centres. On the $\mathrm{x}$-axis is the distance to a small urban centre so that a line shows how 
Figure 2: Income by activity and distance to population centres.

Rural town

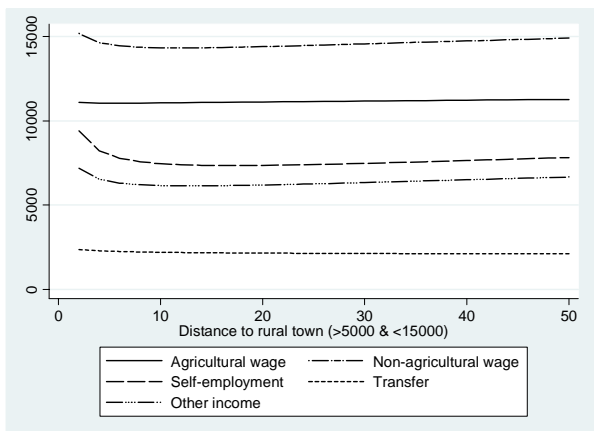

Small urban centre

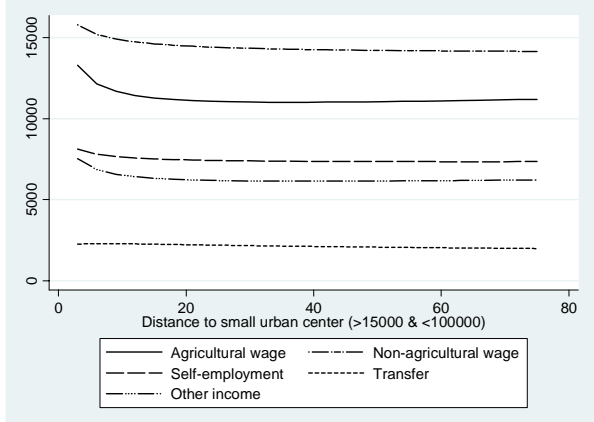

City

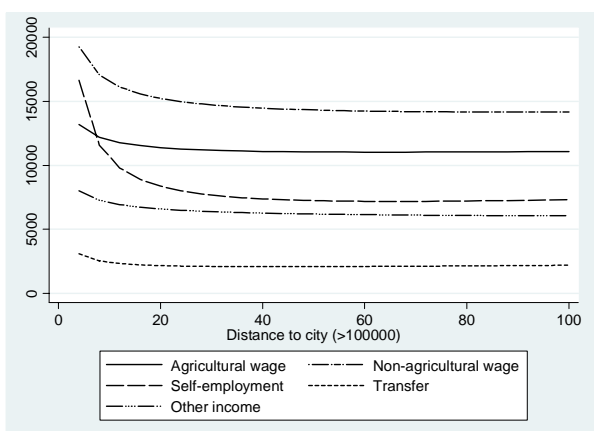


distance to a small urban centre influences the probability of participating in wage activities. Each of the individual lines represents different distances of the households to small towns $(5,20,35$ and $50 \mathrm{~km}$.). If the influences of the two population centres are completely independent the expectation is that the curves would be parallel indicated different distances to towns simply represent a shift in the probability of participating in agricultural employment. The results indicate that there is some relationship between the different population centres although it is not exceptionally strong. As households get further from both centres they are even less likely to participate in agricultural wage activities. For non-farm activities, the interaction effect is even weaker since the lines are nearly parallel. The results do show that the impact on non-farm wage employment participation of being near a small urban centre is much greater than being near a rural town. The second set of graphs in Figure 3 explores the same relationship between small urban centres and cities. Again, the interaction effect is not particularly strong with the lines being nearly parallel for participation in non-farm wage employment and having only moderately changing for agricultural wage employment. Similar results are found when looking at the levels of income. Taken together the results appear to indicate that being close a particular population centre has a strong influence on income-generating activities regardless of whether there is a another centre a bit further away. There only appears to be an influence when a community is fairly remote to begin with.

As noted above, education appears to be a key determinant of the poor's participation in income-generating activities as well as the income earned from those activities. Since Oportunidades supports improved education outcomes, there is some issue of what activities might be available to newly educated individuals. To explore this further, interaction terms between education and distance were included in the probits on participation to see if the influence of education on participation and returns to activities varies depending on location. Figure 4 shows the varia- 
Figure 3: Wage participation and distance to population centres.

Towns versus small urban centres: Agricultural wage

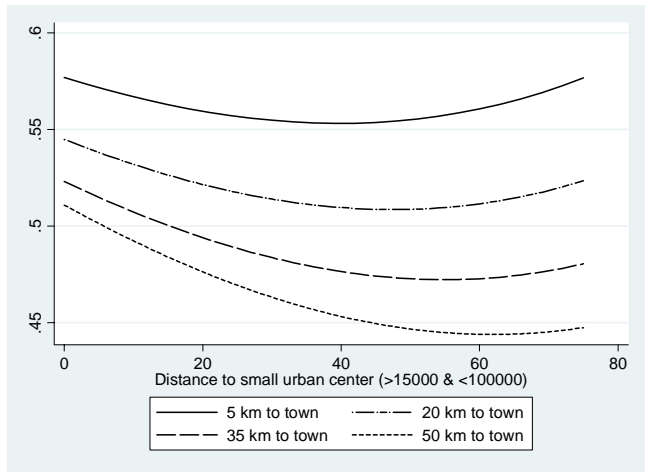

Small urban centres versus cities: Agricultural wage

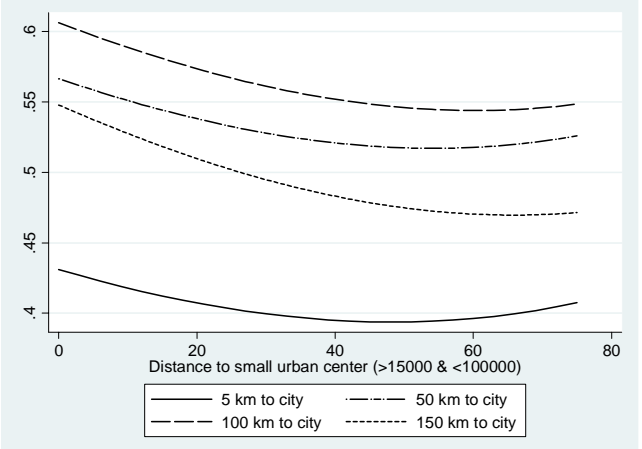

Towns versus small urban centres: Non-farm wage

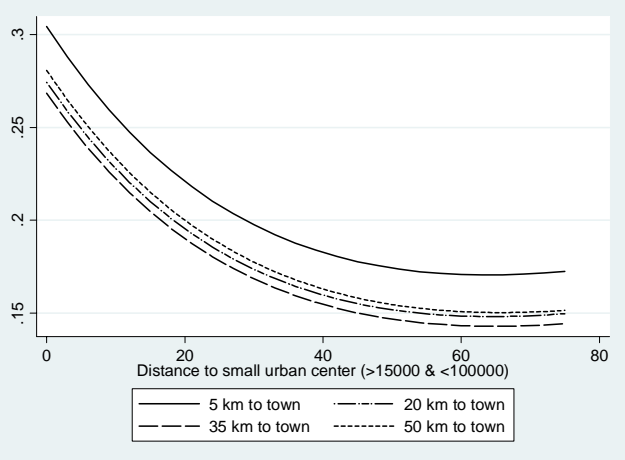

Small urban centres versus cities: Non-farm wage

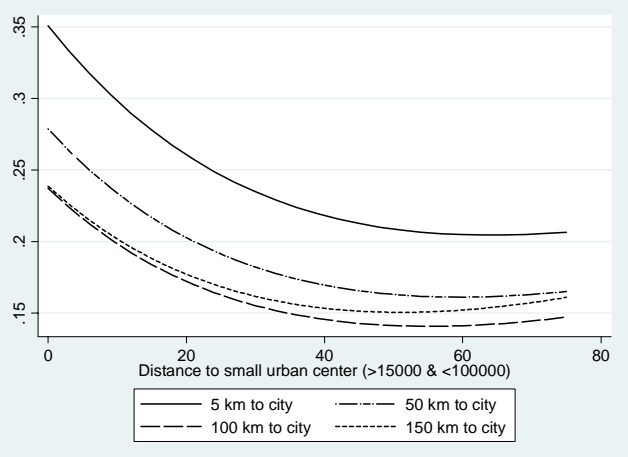


tion in the wage employment participation rates by education level and distance to population centre. Again, the expectation is that without any significant interactions lines should be parallel. The results show that distance appears to interact strongly with having some secondary education. In each of the figures, the interaction with secondary education deviates from the other curves and in some cases quite dramatically. The results indicate that for household heads with secondary education the probability of participation in agricultural wage decreases with distance from towns but increases with distance from small urban centres and cities. Similar analysis for the amount of agricultural income (not shown) indicates higher returns to agricultural wage for secondary schooling the further away from urban centres and cities. For non-farm wage employment, the probability of participation declines more quickly with distance to small urban centres and cities for those with some secondary education compared to other levels of education. Taken together, the results suggest that the returns from secondary education further from urban areas may be found in high productive agricultural employment.

Along with examining how the economic activities vary by education and distance, the relationship between asset ownership, as measured by the puntaje, and distance was also explored. The hypothesis is that those households that are the most asset poor may be unable to participate in activities even if they are close to population centres. The results (not shown) did not bear this out. In fact, there appears to be no interaction between the two and location appears to be equally important for all types of poor. A similar analysis was conducted for the marginality of a community and distance. The results also indicated no interaction between the two.

Table 8 presents the influence of community factors other than distance on the participation of households in the range of economic activities and the returns to 
Figure 4: Wage participation, education and distance to population centres. Rural Town: Agricultural wage Rural Town: Non-farm wage
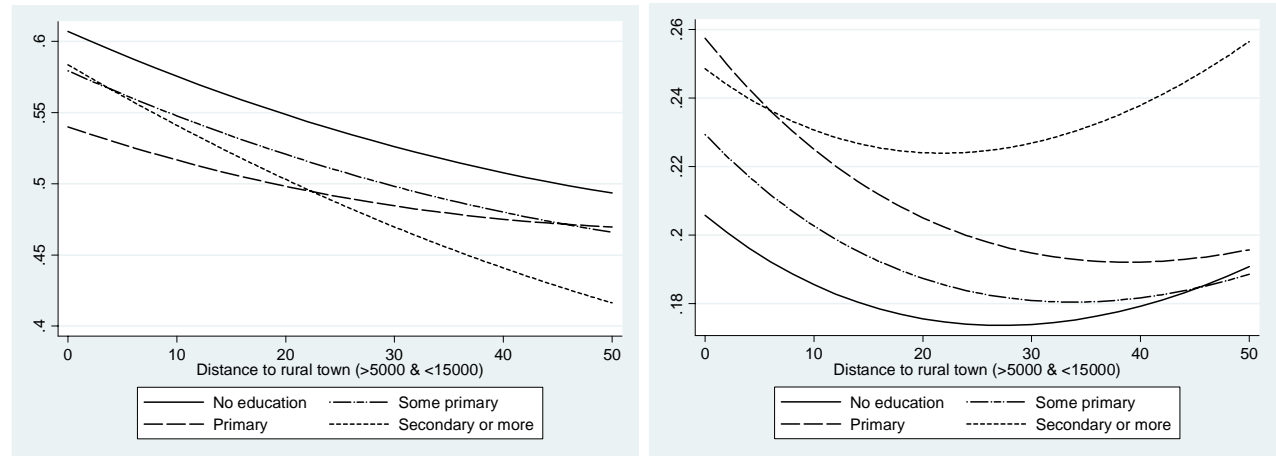

Small urban centre: Agricultural wage

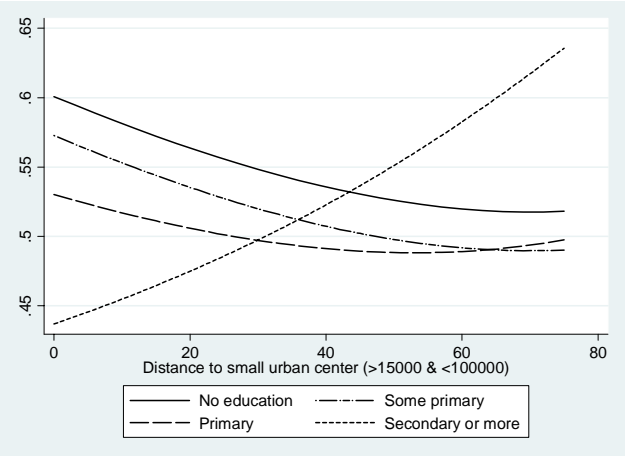

Small urban centre: Non-farm wage

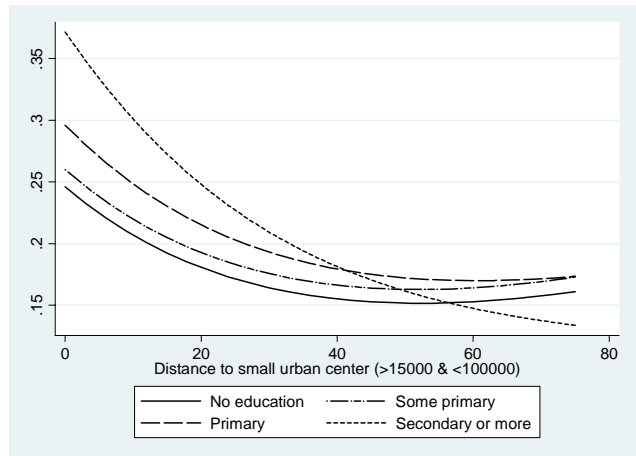

City: Agricultural wage

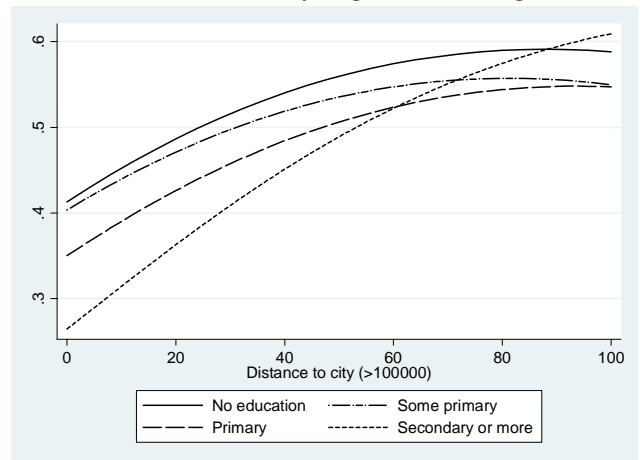

City: Non-farm wage

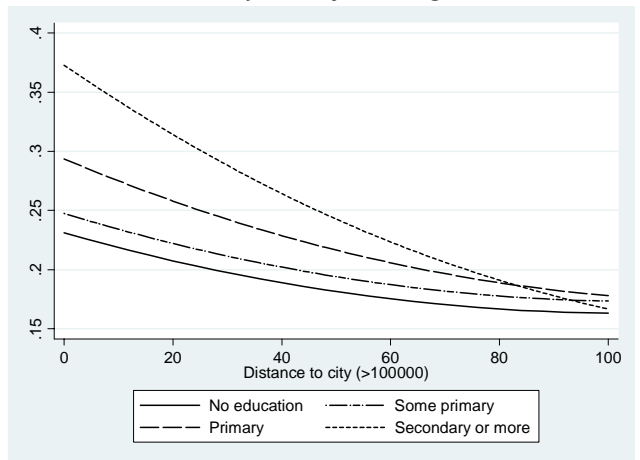


Table 8: Community factors and participation in income-generating activities

\begin{tabular}{|c|c|c|c|c|c|c|c|c|c|}
\hline \multirow[b]{2}{*}{ Participation } & \multicolumn{2}{|c|}{$\begin{array}{c}\text { Agricultural wage } \\
\text { employment } \\
\text { Marginal }\end{array}$} & \multicolumn{2}{|c|}{$\begin{array}{l}\text { Non-farm wage } \\
\text { employment } \\
\text { Marginal }\end{array}$} & \multicolumn{3}{|c|}{$\begin{array}{l}\text { Self-employment } \\
\text { Marginal }\end{array}$} & \multicolumn{2}{|c|}{$\begin{array}{l}\text { Transfers } \\
\text { ginal }\end{array}$} \\
\hline & effect & Z-stat & effect & Z-stat & & effect & Z-stat & effect & Z-stat \\
\hline Population of location & -0.00729 & 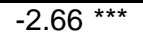 & -0.04706 & -22.02 & k** & 0.03981 & 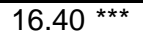 & 0.02176 & 8.50 *** \\
\hline Marginality index & -0.00002 & $-8.90 * * *$ & 0.00002 & 11.58 & k** & 0.00001 & $2.08 * \star \star$ & -0.00004 & $-16.66 * * *$ \\
\hline Access to light & 0.011 & $2.66 * \star \star$ & 0.006 & 1.88 & * & -0.009 & $-2.69 * \star \star$ & -0.019 & $-5.13 * \star \star$ \\
\hline Drainage & 0.007 & $2.34 * \star \star$ & -0.014 & -6.48 & *** & 0.002 & 0.87 & -0.023 & -7.92 *** \\
\hline Diconsa outlet & 0.006 & 2.11 ** & -0.018 & -8.71 & *** & 0.014 & 5.34 *** & 0.028 & 10.43 *** \\
\hline Grocery store & -0.017 & $-5.80 * \star \star$ & 0.005 & 2.49 & k* & 0.016 & 6.26 *** & 0.021 & $7.64 * \star \star$ \\
\hline Household businesses & -0.016 & $-5.85 * \star \star$ & 0.017 & 8.94 & 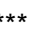 & 0.018 & $7.49 * \star \star$ & 0.032 & $12.64 * * *$ \\
\hline Traveling salesman visits & 0.009 & 2.70 *** & -0.007 & -3.15 & *** & 0.015 & $5.15 * * *$ & 0.036 & 11.66 *** \\
\hline Income level (Logged) & Coef. & t-stat & Coef. & t-stat & & Coef. & t-stat & Coef. & t-stat \\
\hline Population of location (log) & -0.004 & -1.17 & 0.033 & 5.97 & 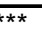 & 0.027 & 4.04 *** & -0.015 & $-2.43 * * *$ \\
\hline Marginality index (log) & -0.090 & $-5.97 * * *$ & 0.096 & 3.45 & *** & -0.329 & $-9.87 * * *$ & -0.249 & -7.92 *** \\
\hline Access to light & -0.024 & $-3.38 * \star \star$ & -0.021 & -1.40 & & -0.038 & $-2.50 * \star *$ & -0.031 & -2.48 *** \\
\hline Drainage & 0.017 & $3.30 * * *$ & -0.042 & -4.48 & *** & -0.062 & $-4.95 * \star *$ & 0.045 & $3.85 * \star *$ \\
\hline Diconsa outlet & 0.003 & 0.55 & -0.029 & -3.07 & *** & -0.039 & $-3.41 * \star \star$ & 0.020 & 1.91 * \\
\hline Grocery store & 0.046 & $9.19 * \star \star$ & 0.036 & 3.78 & k** & 0.007 & 0.62 & 0.054 & $5.04 * * *$ \\
\hline Household businesses & 0.037 & $7.01 * \star \star$ & 0.012 & 1.36 & & 0.010 & 0.97 & 0.015 & 1.48 \\
\hline Traveling salesman visits & 0.043 & 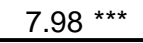 & 0.048 & 5.01 & k* & 0.016 & 1.32 & 0.031 & 2.63 *** \\
\hline
\end{tabular}

those activities for participants. The results indicate that a number of community factors influence income-generating activities of poor rural households. Of particular interest is the marginality index which is a measure of overall community marginality and is the index used to initially identify whether a community should be included in Oportunidades. The higher the value the more marginal (poorer) the community is. The results indicate that, controlling for individual asset poverty (with the puntaje) and community factors, households in communities with a higher marginality index are less likely to participate in agricultural wage employment and receive transfers and more likely to participate in nonfarm age employment and self employment. In more marginal communities, the income earned by participants is substantially lower for agricultural wage and self employment activities, but actually higher for non-farm wage employment.

As with the puntaje, it is interesting to consider whether educational participation is influenced by community-level marginality. To explore this, the probits on participation are run with interaction terms between marginality and the edu- 
cation variables. Results are presented in Table 9 and indicate a strong association between education and marginality. In particular, the results indicate that those with secondary education that live in marginal communities are much more likely to participate in agricultural wage employment and less in non-farm wage employment. This hints at the possibility that there are returns to the educated in agricultural activities under certain conditions; namely in more remote (marginal) communities where agriculture is likely to be a more dominant activity.

Table 9: Schooling and community marginality

\begin{tabular}{|c|c|c|c|c|}
\hline \multirow[b]{2}{*}{ Participation } & \multicolumn{2}{|c|}{$\begin{array}{c}\text { Agricultural wage } \\
\text { employment } \\
\text { Marginal }\end{array}$} & \multicolumn{2}{|c|}{$\begin{array}{l}\text { Non-farm wage } \\
\text { employment } \\
\text { Marginal }\end{array}$} \\
\hline & effect & Z-stat & effect & Z-stat \\
\hline Some primary education & -0.045 & 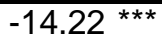 & 0.013 & $5.30^{\star \star \star}$ \\
\hline Primary education & -0.069 & $-16.41 * \star \star$ & 0.028 & $8.45^{\star \star *}$ \\
\hline Some secondary or higher & -0.034 & $-5.68 * \star \star$ & 0.052 & $10.63 * \star \star$ \\
\hline Marginality index & -0.024 & 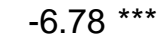 & -0.043 & $-14.45 * \star \star$ \\
\hline Some primary education * marginality & 0.003 & 0.83 & 0.002 & 0.74 \\
\hline Primary education * marginality & 0.019 & $3.56 * \star \star$ & -0.011 & $-2.58^{\star \star \star}$ \\
\hline Some secondary or higher * marginality & 0.210 & 25.52 *** & -0.052 & $-8.33^{* \star \star}$ \\
\hline
\end{tabular}

Notes: Robust test statistics reported; ${ }^{\star * \star}$ indicates signficance at the $99 \%$ level, ${ }^{* \star} 95 \%$ level and * $90 \%$ level.

To investigate whether the asset poor (high puntaje) in marginal communities behave differently than those in less marginal communities, a probit regression with an interaction term between the marginality index and the puntaje was run. Results are presented in Table 10 and strongly suggest that the marginality of the community influences the asset poor differently. In general, it appears that the puntaje leads to greater participation in agricultural wage activities and less in non-farm wage. In highly marginal communities, however, this effect is mitigated. This appears to be because-as seen by the large marginal effect on participation in both agricultural and non-farm wage employment-in marginal communities households are much more likely to participate in agricultural wage in general and less likely 
to participate in non-farm wage employment making the fact the household is asset poor nearly irrelevant.

Table 10: Community marginality and puntaje

\begin{tabular}{|c|c|c|c|c|}
\hline \multirow[b]{2}{*}{ Participation } & \multicolumn{2}{|c|}{$\begin{array}{c}\text { Agricultural wage } \\
\text { employment } \\
\text { Marginal }\end{array}$} & \multicolumn{2}{|c|}{$\begin{array}{l}\text { Non-farm wage } \\
\text { employment } \\
\text { Marginal }\end{array}$} \\
\hline & effect & Z-stat & effect & Z-stat \\
\hline Marginality index & 0.123 & $21.74^{\star \star \star}$ & -0.069 & $-15.68 * \star \star$ \\
\hline Puntaje & 0.045 & $31.74 * \star \star$ & -0.008 & $-7.93 * \star \star *$ \\
\hline Puntaje*marginality & -0.046 & $-26.32 * \star \star$ & 0.008 & 5.68 *** \\
\hline
\end{tabular}

\subsection{Regions}

Finally, we explore the possibility that the results of the analysis are region specific by running the same set of regressions presented above separately for north, central and south Mexico. Full results are available from the authors. The results are largely consistent across the regions although there are some differences in the apparent magnitude of influence of certain variables. Table 11 shows the relationship between education levels and key RIGAs across the three regions. While the influence of primary education and lower education levels are approximately the same across the regions, the influence of secondary education varies substantially. Secondary education has no apparent impact on the probability of participating in agricultural wage employment in the south, but it has a strong negative effect in the central and northern regions. Furthermore, while secondary education has a minimal impact on participation in non-farm wage employment in the south, it has a much larger effect in the centre and north. Finally, for participation in self employment the impact is opposite (negative) for the south versus central and northern regions. Interestingly, for income earned from each activity, the results for non-farm employment for secondary education are larger for the south suggesting those in 
non-farm activities do gain more from education in this activity than in other regions. Returns to secondary education for participants in self employment income are similar across regions and slightly more negative for agricultural wage employment. Taken together, the results suggest that having secondary education provides fewer opportunities, particularly for non-farm wage employment, for those living in the south versus the northern and central regions. For those able to take advantage of the opportunities, they may earn more.

\section{Table 11: Schooling and region}

\begin{tabular}{|c|c|c|c|c|c|c|}
\hline Participation & \multicolumn{2}{|c|}{$\begin{array}{c}\text { Agricultural wage } \\
\text { employment } \\
\text { Marginal }\end{array}$} & \multicolumn{2}{|c|}{$\begin{array}{l}\text { Non-farm wage } \\
\text { employment } \\
\text { Marginal }\end{array}$} & \multicolumn{2}{|c|}{$\begin{array}{l}\text { Self-employment } \\
\text { income } \\
\text { Marginal }\end{array}$} \\
\hline South & & & & & & \\
\hline Some primary education & -0.041 & $-8.83 * \star *$ & 0.006 & $2.21 * \star \star$ & 0.048 & 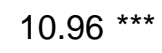 \\
\hline Primary education & -0.054 & $-8.80 * \star \star$ & 0.016 & $4.38^{* \star \star}$ & 0.032 & $5.36 * \star \star$ \\
\hline Some secondary or higher & 0.010 & 1.20 & 0.035 & $6.57^{\star \star \star}$ & -0.058 & $-7.04 * \star \star$ \\
\hline Central & & & & & & \\
\hline Some primary education & -0.041 & $-8.95 * \star \star$ & 0.017 & $4.20^{* \star \star}$ & 0.037 & 10.12 *** \\
\hline Primary education & -0.082 & $-13.21 * \star \star$ & 0.044 & $8.05 * * \star$ & 0.039 & $7.37 * \star \star$ \\
\hline Some secondary or higher & -0.181 & $-20.72 * \star \star *$ & 0.113 & $14.11 * \star \star$ & 0.060 & $7.64^{\star \star \star}$ \\
\hline North & & & & & & \\
\hline Some primary education & -0.035 & $-3.18 * \star *$ & 0.005 & 0.61 & 0.042 & $-14.22 * \star *$ \\
\hline Primary education & -0.054 & $-3.73 * \star \star$ & 0.025 & $2.33^{* * *}$ & 0.026 & $-16.41 * \star *$ \\
\hline Some secondary or higher & -0.156 & $-8.51 * \star \star$ & 0.081 & $5.69 * * *$ & 0.039 & 2.36 *** \\
\hline Income level (Logged) & Coef. & t-stat & Coef. & t-stat & Coef. & t-stat \\
\hline South & & & & & & \\
\hline Some primary education & -0.025 & $-2.50 * \star *$ & 0.052 & $2.30^{* \star \star}$ & -0.003 & -0.16 \\
\hline Primary education & -0.002 & -0.20 & 0.131 & $4.78^{* \star *}$ & 0.039 & 1.74 \\
\hline Some secondary or higher & -0.060 & $-3.81 * \star \star$ & 0.280 & $8.47^{* \star *}$ & 0.196 & $5.59 * \star \star$ \\
\hline Central & & & & & & \\
\hline Some primary education & -0.005 & -0.69 & 0.042 & $3.23 * \star \star *$ & 0.031 & 1.62 \\
\hline Primary education & -0.042 & $-4.14 * \star \star$ & 0.070 & $4.29 * \star \star$ & 0.098 & $3.70^{* \star *}$ \\
\hline Some secondary or higher & -0.036 & 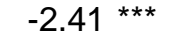 & 0.154 & $7.35 * \star \star$ & 0.212 & $5.62 * \star \star$ \\
\hline North & & & & & & \\
\hline Some primary education & 0.009 & 0.48 & -0.034 & -1.01 & -0.023 & -0.57 \\
\hline Primary education & -0.012 & -0.51 & 0.002 & 0.05 & 0.024 & 0.46 \\
\hline Some secondary or higher & -0.024 & -0.79 & 0.112 & $2.26^{\star \star \star}$ & 0.177 & $2.60 * \star \star$ \\
\hline
\end{tabular}




\section{Conclusions and policy implications}

The objective of this paper is to provide insight into the income-generating activities of poor rural households in Mexico, as a mechanism for considering the role of Oportunidades in the broader anti-poverty Contigo strategy. The results of the data analysis indicate that like most rural households, the extreme poor in Mexico are involved in a range of economic activities. However, there appears to be a much greater concentration in wage employment in general and a greater participation in agricultural wage employment in particular than among the general rural population. This appears to be partially the result of the low asset position of rural households and the inability to participate in wider numbers in more profitable activities.

The particular activities employed by the rural poor are closely linked to their asset position and their location with respect to population centres. Education in particular appears to be a key asset in determining participation in certain activities with higher education levels linked to a shift from agricultural wage employment toward more lucrative non-farm wage employment, especially for those with education levels beyond primary school level. Location matters a great deal in determining the choice of activities with proximity to population centres leading in general to greater wage employment. More specifically, proximity to large urban centres is linked to non-farm wage activities and proximity to smaller centres to agricultural wage employment. In remote areas, self employment, most likely agriculture, increases.

The evidence also suggests that location and having secondary school education interact in way that the returns to higher levels of education vary by location. Higher levels of education appear to lead to greater participation in agricultural wage activities in remote locations, but higher participation in non-farm wage ac- 
tivities in areas closer to large population centres. Results for education also appear to be influenced by the asset position of the household with those with lower assets less able to take advantage of opportunities. Those in more marginal communities with higher education levels are also found to have different opportunities. Finally, across region different impacts of education are found. This analysis then suggests that while education generally appears to have the influence on the activity choice of poor households described above, the magnitude of the impact is mitigated by the asset position of the household as well as location.

These results have implications for how Oportunidades is likely to influence rural poverty through income generation. In fact, the results indicate that Oportunidades is not likely to be neutral in its influence on economic activities. Oportunidades has a strong emphasis on increasing the education of the rural population particularly the children of the poor and has been shown to be effective in improving education outcomes. Now that the program has been in place for nearly a decade, the increased emphasis on schooling will lead to higher schooling levels for young adults. The obvious question is where these labourers will find work. The evidence presented here suggests that the non-farm economy is an important outlet for these workers, but it is unclear whether the opportunities will be there. If not, given the role location plays in income generation it is likely that these newly educated will move to urban centres or at least closer to these centres. Putting Oportunidades in place without complementary policies to promote rural income generation is unlikely to promote rural development and in fact may lead to increased out-migration, especially from more remote areas.

The analysis does not point specifically to clear areas of policy focus for improving the income of the rural poor. While the results suggest a vast majority of households are involved in agricultural wage employment, it also shows higher 
returns from non-farm wage activities. However, focusing just on these activities is only likely to be successful in certain regions, particular near urban centres, where they tend to be more common. It also may depend on what complementary assets are available to specific households. This suggests that anti-poverty policies designed to promote rural income-generation and complement the cash transfers provided by Oportunidades are more likely to be successful if designed for a particular region or location and if they are flexible in their sectoral emphasis. The Microregiones program, which is one component of the Contigo strategy that is specifically geared towards improving income generation, is the program that is most likely to be effective in this regard. Microregiones takes a territorial approach to rural development. As such, it incorporates an assortment of institutional actors including different levels of government and civil society and is open to supporting a range of activities. By focusing broadly on regional development and obtaining local information through local participation, it is in the best position to identify areas for potential income growth and bottlenecks that limit paths out of poverty. The key is that it works in a manner by which it is able to coordinate the activities of these various actors and the plethora of programs under the Contigo umbrella. Only through such coordination is government policy likely to be able to effectively support a set of activities that will allow the rural poor to progress out of poverty. 


\section{References}

[14] Alvarez, C, Devoto, F., .Winters, P. 2006. "Why do beneficiaries leave the safety net in Mexico? A study of the effects of conditionality on dropouts." World Development, Vol. 36(4), April 2008, pp. 641-658.

[14] Barrett, C., and Reardon, T. 2000. Asset, Activity, and Income Diversification among African Agriculturalists: Some Practical Issues. Project report to the USAID BASIS CRSP.

[14] Contigo. 2006. Contigo es Posible. Sistema Internet de Presidencia, Government of Mexico, Mexico, DF, http://www.contigo.gob.mx/ accessed May 16, 2006.

[14] Davis, B., Winters, P., Carletto, G., Covarrubias, K., Quiñones, E., Zezza, A., Stamoulis, K., DiGiuseppe, S. 2007. Cross Country Comparison of Rural Income-generating activities. Manuscript.

[14] Deaton, A. 1997. The Analysis of Household Surveys: A Microeconometric Approach to Development Policy. Baltimore and London: Johns Hopkins University Press and World Bank.

[14] Deb, P., Manning, W., Norton, E. 2005. Modeling Health Care Costs and Counts. Paper presented at the International Health Economics Association 2005 World Congress, Barcelona.

[14] Hertz, T. 2007. The Effect of Non-Farm Income on Investment in Bulgarian Family Farming. Paper presented at the FAO Conference on Migration and Agriculture, Rome, January, 2007.

[14] Fafchamp, M., Shilpi, F. 2003. The Spatial Division of Labor in Nepal, Journal of Development Studies, 39(6), pp. 23-66. 
[14] Skoufias, E. 2005. PROGRESA and Its Impacts on the Human Capital and Welfare of Households in Rural Mexico: A Synthesis of the Results of an Evaluation by IFPRI. International Food Policy Research Institute, Washington, DC.

[14] Taylor, J. E., Yunez-Naude, A. 2000. The Returns from Schooling in a Diversified Rural Economy, American Journal of Agricultural Economics 82(2), pp. 287-297.

[14] Winters, P., Davis B., Corral, L. 2002. Assets, Activities and Income Generation in Rural Mexico: Factoring in Social and Public Capital, Agricultural Economics 27(2), pp. 139-156.

[14] Winters, P., Davis, B., Carletto, G., Covarrubias, K. Stamoulis, K, Quiñones, E., Zezza, A. 2007. Assets, Activities and Rural Poverty Alleviation: Evidence from a Multicountry Analysis, Manuscript.

[14] World Bank. 2004. Poverty in Mexico: An Assessment of Conditions Trends and Government Strategy. World Bank, Washington, DC.

[14] World Bank. 2005. A Study of Rural Poverty in Mexico, in Income Generation and Social Protection for the Poor. World Bank, Washington, DC. 